\title{
The relationship between tutoring mode and learners' use of help tools in distance education
}

\author{
BRUNO DE LIÈVRE ${ }^{1}$, CHRISTIAN DEPOVER ${ }^{1} \&$ \\ PIERRE DILLENBOURG ${ }^{2, *}$ \\ ${ }^{1}$ Educational Technology Unit, Faculty of Psychology and Educational Sciences \\ University of Mons-Hainaut, Place du Parc, 18-B-7000, Mons, Belgium; ${ }^{2}$ Craft- \\ Swiss Federal Institute of Technology, CH-1015, Lausanne, Switzerland \\ (*Author for correspondance, e-mail: pierre.dillenbourg@epfl.ch)
}

Received: 28 January 2005; in final form: 1 April 2005; accepted: 21 December 2005

\begin{abstract}
This article presents an experimental study demonstrating how 120 learners use help tools in a virtual learning set-up. More specifically, several types of tutoring are investigated to find out the extent of the use of help tools in each. The effects of two independent variables which may have an impact on the behaviour of learners are studied: (1) whether or not they have access to a human tutor (HT) and (2) the tutor's means of intervention (reactive or proactive). One of the goals of the study is to determine whether these modes of tutoring can influence positively or negatively distance learners' use of lexical, conceptual, metacognitive and navigational help tools. The results of analysis of variance show that it is useless to prompt (effect of proactivity) learners to use the help that is available to them but that prompting is sometimes more subtle than initially foreseen. It appears that the presence of an HT pushes learners to use help tools, but this effect (of the presence of the HT) is still relatively weak and therefore may not justify the cost of employing a human tutor. It is also important to show the necessary intrinsic quality of the tools made available in order for a given mode of tutoring to have an effect on their use.
\end{abstract}

Keywords: experimental study, distance learning, virtual learning, tutoring, help tools, human tutor, computerised tutor, proactive tutor, reactive tutor

\section{Introduction}

In this article, we deal with tutoring in the distance learning situation. More specifically, we consider different modes of tutoring with the aim of determining their effects on learners. In the context of distance learning, the tutor is considered to be one of the key players in the efficacy of the process. Providing tutorial help to distance students encourages them to be more active during their training, which, in turn, can be expected to reduce the dropout rate. Behind the word 'tutoring' there are a variety of meanings, different practices and 
various modes of intervention in the learning process. What is meant by 'tutoring' is not understood by everyone in the same manner. The modes of intervention by the tutor are not always clearly defined, making it difficult to compare tutoring efficiency in different distance learning situations.

Here we study two modes of tutorial intervention. In the first, called reactive tutoring, tutors react to spontaneous requests for help from learners. In the second, called pro-active tutoring, the tutors intervene in the learners' learning process on their own initiative. These different modes have an impact on the cost of tutoring. For example, should one recommend to designers of distance learning environments the strategy of human tutorial support by telephone, when this must involve frequent, rapid, timely replies - often to questions of the same type? We think that the integration of 'help tools' in training courses can be an appropriate means of providing part of the support the learner needs. However, help tools are not always used by learners in the best possible way. It is therefore worth considering the way in which the mode of tutorial intervention may influence, positively or negatively, the use of help tools integrated in the learning process. The question being asked here concerns the complementarity between the help provided by tools integrated in the learning process and the help provided by a human tutor.

\section{Tutoring, its effects and its modalities}

\section{Tutoring}

Legendre (1993) defines tutoring as 'a form of support covering the entire scholastic activity of the student. (...) The tutor is a guide, an instructor who teaches one person or a small group of pupils at one time' (p. 1379). Tutors may conduct classes in which they are co-present with the students, or their classes may be conducted at a distance. Annoot (2001) says that co-present tutoring allows the student to 'graft himself on to a pre-existing system without questioning it'. (p. 384) - with the explicit aim of reducing the number of failures. This is also one of the aims pursued by the designers of distance learning environments in which tutoring is an integral part. Deschênes \& Lebel (1994) describe the distance tutor as one who is 'the intermediary found in classes where there is no teacher in direct contact with the students' (p. 24). The distance tutor must take on a large part of the responsibilities normally assumed by the classroom teacher: 
- Cognitive support: the tutor must possess disciplinary and methodological skills (Burge et al., 1991; Laurent et al., 1992; Henri \& Kaye, 1985; Denis, 2003).

- Socio-affective and relational support: the tutor must encourage and support the learner (Henri \& Kaye, 1985; Burge et al., 1991; Pettigrew 2001; Glikman, 1999; Gagné et al., 2001).

- Motivational support: the tutor must stimulate and maintain at a high level the motivation of the student (Lebel, 1995; Carrier \& Schofield, 1991).

- Metacognitive support: tutors must help learners develop their abilities so that they realise the need to plan their learning, organise their work, etc (Henri \& Kaye, 1985).

- Administrative and technical support: tutors must help learners through the difficulties they may meet in contact with their learning institution, e.g. at the administrative level and in the use of the communication tools placed at their disposal (Lebel, 1995; Denis, 2003).

According to Paquette (2001), the tutor does not always know which role or responsibilities to priorities. The tutors' own priorities may differ from those of other tutors, from those that the teaching institution ascribes and from those expected by students. Training may be needed to help the tutors carry out their assigned responsibilities.

We see then that the tutorial function needs to be specified before one can determine the effects it may have. In describing the experimental design, below, we shall therefore define, as precisely as possible, the modes of intervention of the tutors and the functions they fulfil.

\section{The effects of tutoring}

The reason most often given to justify employing tutors is that they may help to reduce the high rate of dropout (between 25 and 44\%) associated with the feeling of isolation frequently encountered in the distance learning context (Tinto, 1987; Lebel \& Michaud, 1989; Bertrand et al., 1994; Person et al., 1994; Portway \& Lane, 1997; Depover et al., 1998; Desmarais, 2000; Gagné et al., 2001; Bourdages \& Delmotte, 2001).

The causes of learner dropout are difficult to determine. The analysis of Bertrand et al. (1994) reveals the multiplicity of variables involved (individual, institutional and organisational). As to the means of remedying the problem, many authors point out that tutoring is a 
solution, but when it comes to testing this hypothesis, the results are usually disappointing. Bourdages \& Delmotte (2001) claim that the initiatives to develop tutoring described by Kelly (1993), Blay (1994) and Belawati (1998) did not produce significant results in favour of new tutoring modes. When research results appear in favour of tutoring modes developed to increase the persistence of students in courses, they are often subsidiary results complementary to the principal subject of the research. For example, Towles et al. (1993), who set-up a welcoming structure for learners at the beginning of their training, did not observe any significant difference in persistence between the experimental group (initial welcome by telephone) and the control group (no initial welcome). However, amongst the students in the control group, fewer of those who had previously taken part in another distance learning course withdrew than did those embarking on their first experience of distance learning. These authors (somewhat riskily) deduce from this that tutoring has a positive effect on persistence due to the initial contact the learners had with the tutors on the first distance course they undertook. Bertrand et al. (1994) created an early intervention programme, which they applied to 245 students divided into two groups. The differences observed were contrary to the positive effect expected, which the authors ascribe to reasons of methodology. Though the effect of the treatment on persistence is not shown, on the basis of the comments written by the students involved, the authors infer that the programme nevertheless has an effect on the learner's integration within the educational institution, which is another factor linked to persistence.

The works of Wozniak \& Silviera (2004) point in the same direction when they show that learners need to be guided in using means of communication mediated by computer. Giving them explicit instructions on how to communicate virtually as well as on how to integrate these moments of communication into pertinent tasks which demand production on their part enables learners to attain a level of interactivity that is significantly superior to that of learners who are not fortunate enough to work in the same conditions.

Although there is no confirmation by research results concerning persistence, an early intervention seems to have an effect on other variables capable of influencing persistence (Tinto, 1987). In their research with 928 learners, Gagné et al. (2001) have shown, by means of answers to a questionnaire, that a start-up contact at the beginning of training has a positive influence on the satisfaction of the learner, the number of contacts between the learner and the tutor later on, 
and the quality of the feedback from which the learner benefits. In the results of this research, certain qualities that the learners think the tutor should possess have been put forward: being able to provide high-quality, rapid feedback, being willing to take enough time to understand students' problems and to provide encouragement and emotional support (Sherry, 2000; Pettigrew, 2001). In addition to these, other tutorial qualities are mentioned by the learners: the fact that the tutors favour exchanges, that they bring their own contribution to the work of the learners (by providing resources, for example), that they make sure the learners and what corresponds best to their expectations in the course and that they are reassuring (Burge et al., 1991; Stevenson et al., 1996; Mason \& Weller, 2000).

The attitude of the tutor towards the learner may have an influence on the quality of the relationship established between them. Indeed, in a study involving 101 learners, Schweizer et al. (2001) show that the length of the periods of communication and the involvement of the learners are significantly greater when tutors show empathy than when they remain socially distant. The relationship between a tutor and a learner is one of trust which is built up steadily. Along these lines, Desmarais (2000) notes that when there was a change of tutor during training, the quality of the learners' work was not as satisfactory as when there was no change of tutor during training. Desmarais sees in these results the sign of a specific relationship between tutors and learners which encourages the latter to hand in work to someone they trust, someone who cares about the work they are going to receive and whose comments are personalised.

If tutoring produces these effects, it seems essential to us to be able to show them objectively. Tutoring represents an investment that must be justified by research proving that it is effective. Our research contributes to this goal.

\section{Modes of tutoring}

In distance education literature, there are few studies of the role of tutors and of the relationship between the tutor and the learner (Burge, 1994; Deschênes \& Lebel, 1994; Weedon, 1997). Amongst the tutor's roles, some may be distinguished according to the pedagogical model set-up in distance learning by Power et al. (1994). In most distance learning models, the tutor is limited to playing the role of a corrector or to providing feedback on request, in which case the learners will construct their knowledge in relative solitude (Deschênes 
\& Lebel, 1994; Bernatchez, 1998). In this model, tutors play only a secondary role, which, according to us, does not correspond to the reality of the influence they may have. According to Deschênes \& Lebel (1994), two tutoring models exist in distance learning: on the one hand, the academic model in which the tutor is in control and, on the other hand, the autonomous model in which all the learning dimensions (cognitive, metacognitive and emotional) are taken into consideration and in which the learner interacts with the subject matter in a flexible way. This latter model, developed from constructivist theories, is better adapted to the way we have envisaged the modes of tutoring in the learning environment described in the framework of our research.

The role the tutor plays in the autonomous model seems to us to be close to Weedon's description (1997). Referring to the theories of Vygotsky (1981), Weedon shows that the tutor's function is that of a facilitator allowing the learner to progress towards mastering a higher level of knowledge. The interaction between the tutor and the learner is no longer limited to the monitoring of one by the other but is in fact a task involving them both. Tutors are more than just people who mark the learners' work: they play an active role in the learning process, accompanying learners on the path towards knowledge.

This is what Goodyear et al. (2001) specify when they indicate that the interventions of the tutor can be defined as those of processfacilitator, advisor-counsellor, assessor, content-facilitator, technologist, designer or even manager-administrator. In another analysis related to on-line tutoring, Goodyear (2002) further identifies different elements taken into account by HT tutors. Among these elements, for instance, is the understanding they have of a learner's personality. This insight enables HT tutors to adjust the number of their reactions to the number of requests made by the learner in order to maintain a high quality of interaction between them.

If the active role of tutors is recognised as being a variable that may influence learners' persistence, it then becomes important to consider the way in which tutors fulfil their role (Salmon, 2000). It appears from research that the tutor fulfils different functions, that is to say the functions of cognitive, socio-affective and relational, metacognitive, motivational as well as administrative and technical support.

Many authors emphasise the conditions in which tutors must fulfil their tasks in order to be effective. One of these conditions relates to the timing of the contacts between the tutors and the learners. It seems that the beginning of the learning period is a crucial time to encourage learners' persistence. Bajtelsmit (1988), Towles et al. (1993), 
Gagné et al. (2001) insist on the fact that it is important for the institution to organise and initiate this first contact with the tutor for it to be effective. Burge et al. (1991) justify the institution taking the initiative in contact since, in their study involving 84 tutors and 447 students, they note that learners rarely initiated dialogue with tutors on their own. However we may hope, like Bernatchez (1998), that with the help of contemporary methods of communication, learners may take the initiative in dialogue with the tutor. We agree with Mason (1990) that the mere presence of technology facilitating communication is not enough to make learners suddenly become interactive. It is also necessary to integrate these tools in activities that require the learner to take the initiative in contacting the tutor. Indeed, if the initial contact carries so much importance and if the leaner does not often take the initiative, it seems essential to us for the institution to initiate contact and to adopt a pro-active attitude towards the learner.

Glikman (1999) puts forward several reasons for the fact that learners do not take the initiative in asking for help from tutors:

- some learners get together in order to find the information they need in other resources at their disposal;

- other learners do not dare to ask the tutors for help for fear of having to reveal their lack of understanding;

- a few no longer ask the tutors for help because their first contact with them was unsatisfactory.

We also think, like Posner et al. (1992) and Dijkstra et al. (1999), that another reason for the low number of requests for help may be a lack of awareness on the part of the learners that they need any help. Gilkman (1999) also insists on the fact that, even though they do not often seek the help of the tutors, the majority of learners recognise the positive contribution of these tutors. The fact that tutors are available seems, in the eyes of the learners, to be more important than calling on them regularly. This attitude of learners is also featured in the Taplin et al. (2001) study involving 712 students. Furthermore, these authors note that the learners' requests for help are not related to their level of achievement. The learners explain that they first try to solve a problem on their own. Karabenick \& Knapp (1991), in their analyses of 612, 541 and 386 subjects, show that the most active learners and the most anxious to finish their work are those who ask for the most help.

These different research results confirm the need to study the way in which tutors intervene in a distance learning context: should they 
let the learner ask for help (reactive attitude) or should they intervene in the learner's work (pro-active attitude)? Are help tools going to be used more, or less, intensively in these different modes of tutorial intervention? Are they going to be used more, or less, appropriately? These are the questions to which our research is going to try to provide some answers.

\section{Hypotheses}

\section{Origin of the hypotheses}

Our hypotheses are based on evidence from the research of Burge et al. (1991), Crook (1994), Collis \& Pals (1998), Bernatchez (1998), Glikman (1999) and Pettigrew (2001) whose conclusions seem to indicate that help tools, placed at the disposal of learners, are underused in a learning context. Crook's analysis (1994), carried out on six groups of students enrolled in a course, reveals only minimal use of electronic mail as a work-tool. Its use is often limited to a request for help addressed to another learner or to the teacher, without any real dialogue taking place. Collis \& Pals (1998) and Burge et al. (1991) refer to results which point in the same direction. Pettigrew (2001) shows that out of 48 students involved in a distance course, only 10 called on help provided outside compulsory contacts. Of these 10 students, two may be considered as having used help with a view to solving learning problems: that is, they asked for help in connexion with the content and the work method. The other eight students who availed themselves of help tools kept to brief, technical communications. Glikman (1999) shows similar results. That is, the majority of learners do not often use the help available, even though they consider that formulating a request for help is a good means of learning, chiefly because the request is preceded by recognising the difficulty encountered (Taplin et al., 2001).

Experiments connected with the use of help tools in computerised learning environments have revealed a similar tendency, which is that they are rarely used. In previous studies (Deschryver et al., 1994), we have been able to observe that learners who are not very familiar with the content use the resources placed at their disposal very differently than anticipated. These new learners make only minimal use of all the resources at their disposal. Several explanations are put forward by Glikman (1999): either the learners believe they can find the information they need on their own or they are afraid of showing they need 
help because of shyness or a fear that a lack of knowledge will be revealed. Authors like Karabenick \& Knapp (1991) and Pettigrew (2001) are in favour of this second explanatory hypothesis. Like Posner et al. (1992) and Dijkstra et al. (1999), we think that one explanation may be that the learners do not know what sort of help these tools can offer, but that it is also possible that they do not use the help tools because the learning situation does not insist on their use. In fact, learners use help tools when they realise their advantages. But they only discover these advantages when they are obliged to use them in order to continue their learning or if the system makes them discover them.

Concerning the stimulation of learners to use help tools, we can refer to the concept of 'scaffolding' defined by Wood et al. (1976) as the control of 'aspects of the task which are initially beyond the student's capabilities in order to allow him to concentrate on those which are not beyond his capabilities' (p. 9). In order to encourage access to a higher level of knowledge, Young (1993) and Choi \& Hannafin (1995) have reflected on the type of tutorial intervention, which may be adapted to the needs of the learner and lead them progressively to an independent use of resources at their disposal. Collins (1996) suggests that the scaffolding must consist of well-timed interventions: tutors must intervene at precise moments. Precisely when they must intervene still needs to be defined. To be more specific concerning these interventions, we may refer to the research of Hardy (1992) on telematic tutoring which shows that a Socratic dialogue consisting of asking for the learner's opinion, being thus pro-active, facilitates learning. Tutorial interventions representing scaffolding are considered necessary by Mason (1990), who believes that learners are not suddenly going to become active once help is available. Like Power et al. (1994), we believe that the pro-active approach implies that learning is a part of a socialisation process during which requests for help need to be foreseen.

As to the presence or absence of a human tutor, Salomon et al. (1989) consider that the support provided by a human expert allows learners to reach a level of knowledge that they would not be able to attain as easily on their own. When resources are not used in the best possible way, a well-adapted intervention by a human tutor, representing scaffolding, may remedy this state of affairs. It seems to us that another justification for the contribution of a human tutor may be inferred from research by Bajtelsmit (1988), Burge et al. (1991), Towles et al. (1993), and Gagné et al. (2001) who show that an initial 
contact between the human tutor and the learner is essential in order to promote motivation and the quality of future communications. If this initial contact is very important, it is because it allows 'both partners in the framework to decide on future modes of communication, to clarify their roles, to say what their expectations are and to create an emotional climate which favours continuing communication' (Gagné et al., 2001, p. 80.). This initial contact is more easily established in the framework of a dialogue maintained by the learner with a human tutor than when this contact takes place between a learner and a computerised system, however sophisticated it might be.

Our aim is to verify the impact of this pro-active behaviour and the impact of intervention by a human tutor on the use of help tools in the context of distance learning.

\section{Hypotheses}

Our hypotheses take into consideration two principal effects: the type of tutoring (pro-active or reactive) and access to human tutoring (HT) or to computer-generated tutoring (CT), and an interactions effect between these two variables.

- Hypothesis 1 (relates to the effect of pro-active tutoring on the use of help tools): Pro-active tutoring leads to a greater use of help tools than reactive tutoring.

- Hypothesis 2 (relates to the effect of access to an HT or to a CT on the use of help tools): Access to an HT leads to a greater use of help tools than does access to a CT.

- Hypothesis 3 (relates to the effect of interaction between proactive tutoring and access to an HT): Pro-active tutoring has a greater effect on the use of help tools when the learners have access to an HT.

These different hypotheses will be tested for the different types of help being considered (metacognitive help, lexical help, conceptual help and navigational help).

For our purposes, "tutoring" refers to both HT and CT unless otherwise specified.

\section{The experimental design}

In presenting the experimental design used to test these hypotheses, we shall specify the characteristics of our sample and the context in 
which we operated. We shall then describe the environment in which the learning took place and lastly we shall enumerate the independent variables integrated in the experimental design.

\section{Sampling process}

The context was that of a university training course during which the students had to participate in practical course-work relating to teaching and learning models. The practical work was given to the students in the form of distance learning, including software (developed with the Authorware authoring system) and a synchronous communication tool (based on Intel's Proshare software).

The approach we chose was quantitative (an experimental apparatus was set-up). It was also ecologically valid in the sense that the training in which the learning environment was placed figured in the programme of studies of the Faculty of Psychology and Education Sciences of Mons-Hainaut University with students in a real learning situation.

Another characteristic of our research was the fact that it ran over a relatively long period of time compared to most other studies of this kind. The average time spent per student was almost $5 \mathrm{~h}$.

The sample was made up of 120 students taking part in a course on the models and processes of learning. Each of the learners dealt with seven cases describing the situation of a pupil in difficulty. Each of these seven situations was presented in an identical order for all the learners. Each learner participating in the course was asked to follow three or four one-and-a-half hour sessions spread over three or four consecutive weeks. These students had no experience of distance learning.

\section{The learning environment}

The learning environment (Figure 1) presented seven cases. For each case, the learner's task was structured in three phases. During the situation analysis phase, the learners were acquainted with learning difficulties that were described to them. They were asked to investigate how these difficulties show up in everyday life by consulting lists of effects or symptoms which shed light on the nature of the difficulty.

The identification phase required the learners to identify with precision the learning difficulties pupils encountered during the preceding phase by associating them with one or several theoretical principles capable of explaining their origin. In order to carry out this task, the 


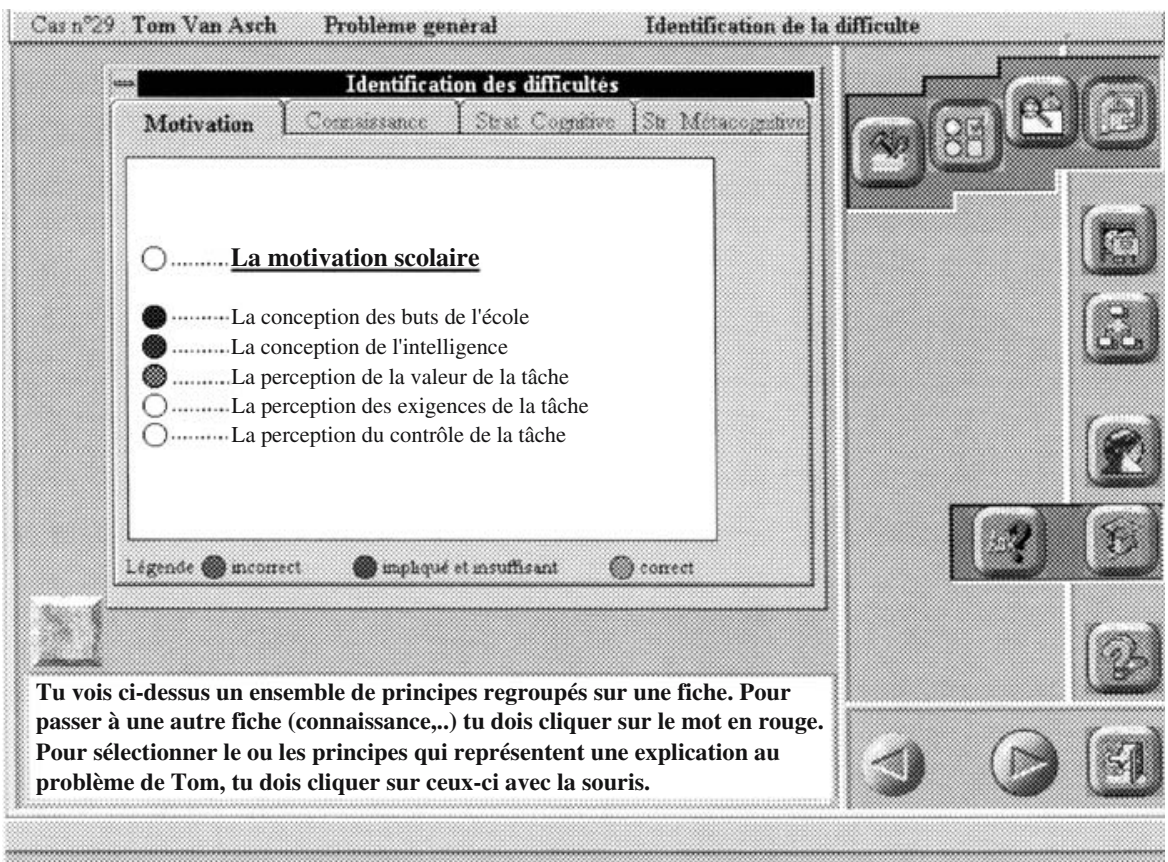

Figure 1. The learning environment used by the learner.

learners selected principles (motivation in school, knowledge, strategies, etc.) that seemed to correspond to the pupils' difficulties. The third phase was to propose a solution for solving the learning difficulties they had identified, illustrating them using the problem described and linking them to the theoretical bases.

Different help tools were constantly available (represented by the buttons in the zone on the right side of Figure 1). These tools were divided into four categories: lexical help, conceptual help, navigational help and metacognitive help.

- The lexical help provided the learners with succinct definitions of concepts used in the software.

- The conceptual help presented more detailed information than that given in the lexical help. It offered conceptual interactive cards showing relationships between concepts; it gave access to numerous examples illustrating the concepts and allowed the learners to verify their understanding of the concepts through self-correcting exercises.

- The metacognitive help allowed learners to obtain information relating to their steps toward learning, in order to analyse their 
progress. One tool was a control panel which displayed what they had already done and what they still had left to do. Another tool traced the actions they had already carried out. Learners could also have access to the questions which they had been asked and to the answers they had given, as well as to comments and advice from which they could benefit. This could possibly help them to deal with a new situation on the basis of their previous learning activities.

- The navigational help gave learners the possibility to obtain information relating to the way in which they should manipulate the software (access a phase, answer questions, quit, ask for help, use a communication tool, etc.) and also information relating to procedures they had to accomplish (the different work phases and their objectives, the criteria which determined access to the questions or to a later work phase, etc).

\section{The independent variables}

The experimental groups are described (Table 1) by the crossing of the two independent variables: access to HT or to CT and reactive or pro-active tutoring.

Access to an HT means the learner could chat with that HT tutor through a semistructured dialogue interface (Figure 2). Once the tutor's help was requested, a dialogue space opened up allowing the students and the tutor to engage in dialogue.

When there was no HT tutor, the learners received CT tutoring. In that case, the communication with the HT function was deactivated.

The pro-active mode of intervention consisted of proposing ways of proceeding to the learner, administering advice, asking questions, etc.,

Table 1. Independent variables and composition of experimental groups

\begin{tabular}{|c|c|c|}
\hline & Reactive tutoring & Pro-active tutoring \\
\hline $\begin{array}{l}\text { Access to a } \\
\text { CT tutor }\end{array}$ & $\begin{array}{l}\text { Twenty-nine subjects have access } \\
\text { to help tools do not have access to } \\
\text { a human tutor do not have access } \\
\text { to pro-active messages }\end{array}$ & $\begin{array}{l}\text { Thirty subjects have access to } \\
\text { help tools do not have access to } \\
\text { a human tutor have to pro- } \\
\text { active messages }\end{array}$ \\
\hline $\begin{array}{l}\text { Access to an } \\
\text { HT tutor }\end{array}$ & $\begin{array}{l}\text { Thirty-one subjects have access to } \\
\text { help tools have access to a human } \\
\text { tutor have access to pro-active } \\
\text { message }\end{array}$ & $\begin{array}{l}\text { Thirty subjects have access to } \\
\text { help tools have access to a } \\
\text { human tutor have access to } \\
\text { pro-active messages }\end{array}$ \\
\hline
\end{tabular}




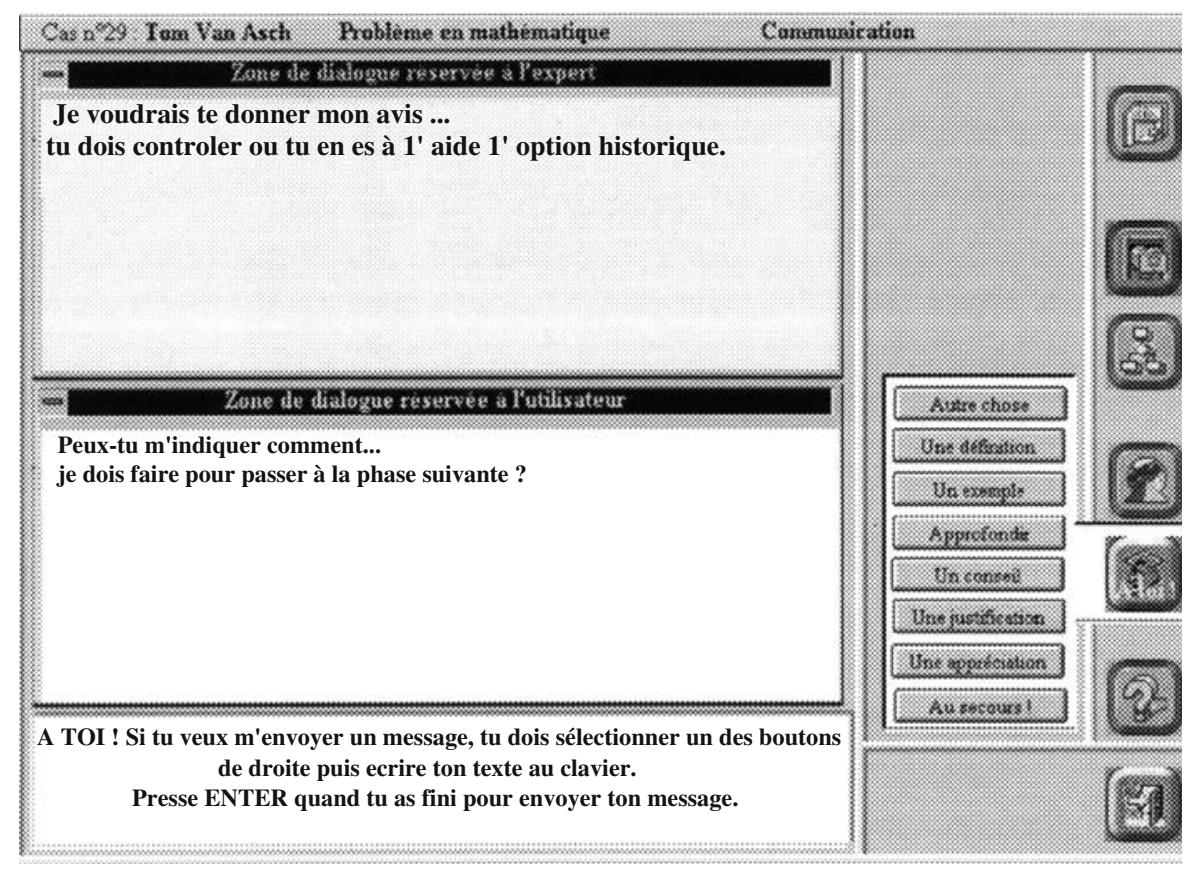

Figure 2. A semi-structure communication interface.

without waiting to be called upon by the learner. The actions taking place in the pro-active mode were initiated on the basis of well-defined criteria, which we shall describe in detail shortly. The mode of intervention described as reactive consisted of waiting for a request from the learner.

Among the messages sent by the tutor to the learner, some may be described as automatic and others as personalised. The automatic messages were delivered by the computer system and appeared in a window superimposed over the learner's work zone. The automatic messages appeared each time a criterion of activation was satisfied. They could thus be sent to the learner either systematically by the CT or by the HT (who activated a function via the keyboard making the message appear in the communication interface). The personalised text-format messages were composed by the human tutor using a keyboard. Below, we describe the modes according to which each group benefited from automatic messages or personalised messages (Table 2).

In Table 3, we present some examples of automatic messages and their criterion of activation. These messages were compiled from a list used during a previous experiment on a prototype version. 
Table 2. Description of the methods according to which each group receives automated or personalised messages

\begin{tabular}{|c|c|c|}
\hline & Reactive tutoring & Pro-active tutoring \\
\hline $\begin{array}{l}\text { Access to a } \\
\text { CT tutor }\end{array}$ & $\begin{array}{l}\text { The learners could use only the } \\
\text { help tools installed on the } \\
\text { computer }\end{array}$ & $\begin{array}{l}\text { The automatic messages were sent } \\
\text { by the CT according to certain } \\
\text { criteria: the learners' progress, the } \\
\text { quality of their responses, the } \\
\text { length of a period of inactivity }\end{array}$ \\
\hline $\begin{array}{l}\text { Access to an } \\
\text { HT tutor }\end{array}$ & $\begin{array}{l}\text { Some automatic messages were } \\
\text { supplied to reply to questions } \\
\text { asked by the learners but the } \\
\text { HT wrote most of the messages }\end{array}$ & $\begin{array}{l}\text { The HT applied the same criteria } \\
\text { as the CT to send 'automatic } \\
\text { messages'. In addition, the per- } \\
\text { sonalised messages were created } \\
\text { by the HT either to answer the } \\
\text { learner or when there was no rel- } \\
\text { evant pre-recorded message }\end{array}$ \\
\hline
\end{tabular}

Table 3. Examples of automatic messages and of their criterion of activation

\begin{tabular}{|c|c|}
\hline Message & Criterion of activation \\
\hline $\begin{array}{l}\text { I'd like you to know that this phase is not } \\
\text { accessible for you in the present state of your } \\
\text { work. You should check your progress with } \\
\text { the record-sheet in the history option and see } \\
\text { whether you have all the information and } \\
\text { whether you have answered all the questions... }\end{array}$ & $\begin{array}{l}\text { Moves to a new phase when the } \\
\text { preceding phase has not been } \\
\text { completed }\end{array}$ \\
\hline $\begin{array}{l}\text { You have made a lot of mistakes in answering } \\
\text { the questions; you should go over the theory } \\
\text { related to these questions again }\end{array}$ & $\begin{array}{l}\text { Score of less than } 60 \% \text { for } \\
\text { answers to questions }\end{array}$ \\
\hline $\begin{array}{l}\text { I'd like you to know that I think you have all } \\
\text { the information necessary to answer the ques- } \\
\text { tions. You should check your progress with the } \\
\text { record-sheet in the history option and see } \\
\text { whether the question button has not been } \\
\text { activated... }\end{array}$ & $\begin{array}{l}\text { Does not answer the questions } \\
\text { even though in possession of the } \\
\text { necessary information }\end{array}$ \\
\hline $\begin{array}{l}\text { You use inadequate strategies; you should } \\
\text { check in the history option what you have } \\
\text { already accomplished, which may help you } \\
\text { understand why you went wrong }\end{array}$ & $\begin{array}{l}\text { Selects a criterion when already } \\
\text { told following an earlier choice } \\
\text { that this criterion could not be } \\
\text { appropriate }\end{array}$ \\
\hline
\end{tabular}


Table 3. Continued

\begin{tabular}{|c|c|}
\hline Message & Criterion of activation \\
\hline $\begin{array}{l}\text { You choose many inadequate criteria! Perhaps } \\
\text { you should go back and re-read the description } \\
\text { of the problem? If the terms are difficult, use } \\
\text { the glossary or the conceptual help }\end{array}$ & Many wrong choices $(\leq 5)$ \\
\hline $\begin{array}{l}\text { I'd like you to know that I think you have } \\
\text { answered the questions in this phase. You } \\
\text { should check where you are with the record- } \\
\text { sheet in the history option and see which phase } \\
\text { you can go on to... }\end{array}$ & $\begin{array}{l}\text { Does not move on to the next } \\
\text { phase even though the informa- } \\
\text { tion has been used and the ques- } \\
\text { tions answered }\end{array}$ \\
\hline $\begin{array}{l}\text { You have not done anything for a long time } \\
\text { Can you explain to me why you have gone } \\
\text { back to a previous phase and what you } \\
\text { thought you might gain from so doing? }\end{array}$ & $\begin{array}{l}\text { After } x \text { seconds of inactivity } \\
\text { Returns to a previous phase al- } \\
\text { though capable of working in the } \\
\text { present one }\end{array}$ \\
\hline
\end{tabular}

\section{Analysis and discussion of the results}

When analysing the results, we shall consider each of the kinds of help in turn and analyse the influence of (a) the mode of intervention (pro-active or reactive) and (b) access to an HT or to a CT.

\section{The metacognitive help}

In Table 4 below, we find the number of times that the learner used help (activations by the learner of the metacognitive help), the number of times the tutor (whether HT or CT) prompted the learner to use the metacognitive help and the number of items of metacognitive information the tutor sent the learner through the communication interface.

Tutoring in the pro-active mode increases the number of activations by the learner of metacognitve help

The average number of activations of the metacognitive help (Table 4) was higher when the tutoring mode was pro-active (3.05 for the pro-active mode with access to the CT and 3.42 for the pro-active mode with access to the HT) than when it was reactive. The analysis of the variance (Table 5) shows a significant VVS effect at 0.000 in favour of the pro-active mode. Only the first hypothesis, which postulates that the pro-active mode of intervention results in an increase 
Table 4. Average number of items of metacognitive help

\begin{tabular}{lllll}
\hline & $\begin{array}{l}\text { Reactive } \\
\text { access } \\
\text { to the } \\
\text { CT tutor }\end{array}$ & $\begin{array}{l}\text { Pro-active } \\
\text { access } \\
\text { to the } \\
\text { CT tutor }\end{array}$ & $\begin{array}{l}\text { Reactive } \\
\text { access } \\
\text { to the } \\
\text { Ht tutor }\end{array}$ & $\begin{array}{l}\text { Pro-active } \\
\text { access } \\
\text { to the } \\
\text { HT tutor }\end{array}$ \\
\hline $\begin{array}{l}\text { Activations by the learner } \\
\text { of the metacognitive help } \\
\begin{array}{l}\text { Promptings by the tutor to } \\
\text { use the metacognitive help }\end{array}\end{array}$ & - & 3.05 & 1.71 & 3.42 \\
$\begin{array}{l}\text { Items of metacognitive } \\
\text { information transmitted } \\
\text { by the tutor }\end{array}$ & - & 0.29 & 0.13 & 0.17 \\
\hline
\end{tabular}

Table 5. Results of the analysis of variance relating to the activations by the learner of the metacognitive help

\begin{tabular}{|c|c|c|c|c|c|c|c|c|}
\hline \multirow{2}{*}{\multicolumn{3}{|c|}{$\begin{array}{l}\text { Hypothesis } 1 \text { : } \\
\text { Pro-active }>\text { reactive }\end{array}$}} & \multicolumn{3}{|c|}{$\begin{array}{l}\text { Hypothesis } 2 \text { : } \\
\text { Access > no access to } \\
\text { the human tutor }\end{array}$} & \multirow{2}{*}{\multicolumn{3}{|c|}{$\begin{array}{l}\text { Hypothesis } 3 \text { : } \\
\text { Interaction effect }\end{array}$}} \\
\hline & & & $(\mathrm{HT})$ & (CT) & & & & \\
\hline \multirow{2}{*}{$\begin{array}{l}F \text { ratio } \\
92.33\end{array}$} & \multicolumn{2}{|c|}{$\begin{array}{l}\text { Levels of } \\
\text { significance }\end{array}$} & $F$ ratio & \multicolumn{2}{|c|}{$\begin{array}{l}\text { Levels of } \\
\text { significance }\end{array}$} & $F$ ratio & \multicolumn{2}{|c|}{$\begin{array}{l}\text { Levels of } \\
\text { significance }\end{array}$} \\
\hline & VVS & 0.000 & 2.54 & NS & 0.111 & 0.38 & NS & 0.534 \\
\hline
\end{tabular}

in the number of uses of help on the part of the learner, is validated. The other two hypotheses are invalidated.

To explain these results, we shall consider two possible explanations: the influence of the promptings of the tutor (that is the fact that the tutor indicates for the learner to use the metacognitive help) and the influence of items of metacognitive information which the tutor gives the learner when they are engaged in dialogue (for example when tutors ask learners to be attentive to the feedback they have received to help them understand their mistakes).

First explanation: the learner takes into account the promptings of the tutor to use the metacognitive help

In this respect, we may say that:

- Pro-active tutoring prompts the learner to use the metacognitive help equally with or without the availability of an HT tutor. In 
Table 4, we notice that the number of promptings was greater with pro-active CT tutoring (0.29) than with pro-active HT tutoring (0.17). However, from a statistical point of view, we must consider that there is no significant difference in terms of the number of promptings (NS at 0.27 on the $t$ test between the averages).

- At the individual level, the learner takes more systematic notice of pro-active promptings when HT tutors are accessible than when they are not. Table 6 shows Bravais Pearson's correlation coefficient between the number of promptings and the number of activations of the metacognitive help. This coefficient was significant $(r=0.187 \mathrm{VVS}$ at 0.007$)$ with pro-active HT tutoring but not with pro-active CT tutoring.

When the tutoring mode is pro-active, we thus observe no difference (NS at 0.27 on the t test between the averages) in terms of the number of promptings, whether dealing with the HT tutor or the CT tutor, whereas we observe the presence of a significant correlation $(r=0.187$ VVS at 0.007) between the number of promptings and the number of uses of the metacognitive help when the HT is accessible.

Second explanation: the learner who receives metacognitive information is stimulated to use the metacognitive help more intensively

Concerning this explanation, we may say that:

- Learners do indeed call on metacognitive help more often when they receive metacognitive information. The correlation coefficient $(r=0.183)$ in Table 6 shows that a significant relationship exists (VVS at 0.008 ) between the number of items of information administered by the pro-active HT and the number of requests for metacognitive help.

- Nevertheless the number of items of information and promptings has a limited influence on the use of the metacognitive help. We

Table 6. Bravais Pearson correlation coefficients between the number of information requests and the number of activations of the metacognitive help (first line) and between the number of occurences of metacognitive information transmitted by the tutor and the number of activations of the metacognitive help (second line)

\begin{tabular}{lllllll}
\hline & \multicolumn{2}{l}{ Pro-active CT tutor } & \multicolumn{4}{c}{ Pro-active HT tutor } \\
\hline Promptings & $r=0.131$ & NS at & 0.058 & $r=0.187$ & VVS & 0.007 \\
Items of information & - & - & - & $r=0.183$ & VVS & 0.008 \\
\hline
\end{tabular}


must analyse the influence of the promptings and the items of information with caution. Indeed, if they are significant, the correlation coefficients (Table 6) related to the items of information and to the promptings are not very high $(r=0.183$ and $r=0.187$ respectively). The regression analysis (Table 7) reinforces our caution as to the interpretation of these results: in fact, it reveals that the combination of these two variables accounts for only $5 \%$ of the global explanation $\left(R^{2}\right.$ of 0.053$)$ of the use of the metacognitive help. If we try to give a meaning to the Beta values $($ Beta $=0.139$ for the promptings and Beta $=0.145$ for the items of information), which represent the intensity of the explanation of these variables in the global variance, we can say that these values are

- positive (the greater the number of promptings and items of information, the more the learner uses the metacognitive help),

- significant (the items of information and the promptings systematically influence the use of the metacognitive help),

- low (the items of information and the promptings play only a limited part in explaining the use of the metacognitive help), and

- equivalent (the promptings do not have a greater explanatory value than the items of information).

Third explanation: pro-active tutoring has an effect on the use of the metacognitive help which may be explained by the 'social presence' of the HT tutor

The attentive presence of the HT tutor, shown by pro-active interventions in the work of the learner, might stimulate spontaneous use of the metacognitive help. It may be that this is a general characteristic of pro-activity linked to HT tutoring. More than the content of the interventions, it is the mode of intervention of the HT tutors which, because it gives the learners the impression that someone is taking an interest in them, may captivate their attention. This is what some call

Table 7. Results of the regression analysis for the pro-active tutoring mode carried out by an HT tutor, concerning the metacognitive help

\begin{tabular}{lllllllllll}
\hline \multicolumn{3}{c}{$\begin{array}{l}\text { Pro-active access to the HT } \\
\text { tutor }\end{array}$} & & \multicolumn{1}{c}{$\begin{array}{l}\text { Beta } \\
\text { value }\end{array}$} & & \multicolumn{3}{c}{$t$ sign. } \\
\hline$R$ & 0.229 & $F$ & 5.754 & & Promptings & 0.139 & 1.968 & 0.050 & $\mathrm{~S}$ \\
$R^{2}$ & 0.053 & $F$ sign. & 0.004 & VVS & Items of information & 0.145 & 2.049 & 0.042 & $\mathrm{~S}$ \\
\hline
\end{tabular}


'social presence' (Bernard \& Naidu, 1990; Gregor \& Cuskelly, 1994). It is thought to stimulate learners to stay in a state of cognitive awareness and to use the forms of help placed at their disposal. The greater use of the metacognitive help on the part of the learners who benefited from the pro-active tutoring can be explained by the fact that the tutor intervenes more frequently on the learner's behalf. The tutors make their presence felt more intensively and the learners, sensing this, spontaneously use the help tools. The less frequent use of the metacognitive help by the learner who benefited from reactive HT tutoring confirms the effect of this 'social presence'. Pro-active tutors would appear then, by their presence, to be sufficient to stimulate learners to use the metacognitive help; the opposite effect is observed when this presence is felt less.

\section{The lexical help}

Pro-active tutoring increases the use of the lexical help

As with the metacognitive help, we see that pro-active tutoring has an effect since the learners used the lexical help significantly more often in the pro-active mode (1.35 and 1.09 , Table 8$)$ than in the reactive tutoring mode $(0.70$ and 0.85 , Table 8$)$.

The analysis of variance (Table 9) confirms that there is a significant effect due to the pro-active attitude of the tutor but no effect due to the presence of a human tutor or to interaction. Only the first hypothesis, which postulates that the mode of intervention of the tutor increases the use of the lexical help, is thus confirmed. The other two hypotheses are invalidated.

Table 8. Average number of items of lexical help

\begin{tabular}{lllll}
\hline & $\begin{array}{l}\text { Reactive } \\
\text { access } \\
\text { to the } \\
\text { CT tutor }\end{array}$ & $\begin{array}{l}\text { Pro-active } \\
\text { access } \\
\text { to the } \\
\text { CT tutor }\end{array}$ & $\begin{array}{l}\text { Reactive } \\
\text { access } \\
\text { to the } \\
\text { HT tutor }\end{array}$ & $\begin{array}{l}\text { Pro-active } \\
\text { access } \\
\text { to the } \\
\text { HT tutor }\end{array}$ \\
\hline $\begin{array}{l}\text { Activation by the learner of the } \\
\text { lexical help }\end{array}$ & 0.70 & 1.35 & 0.85 & 1.09 \\
$\begin{array}{l}\text { Promtings by the tutor to use } \\
\text { the lexical help }\end{array}$ & - & 0.32 & 0.09 & 0.40 \\
$\begin{array}{l}\text { Items of lexical information } \\
\text { transmitted by the tutor }\end{array}$ & - & - & 0.25 & 1.37 \\
\hline
\end{tabular}


Table 9. Results of the analysis of variance relating to activation by the learner of the lexical help

\begin{tabular}{|c|c|c|c|c|c|c|c|}
\hline \multicolumn{3}{|c|}{$\begin{array}{l}\text { Hypothesis } 1 \text { : } \\
\text { Pro-active }>\text { reactive }\end{array}$} & \multicolumn{2}{|c|}{$\begin{array}{l}\text { Hypothesis } 2 \text { : } \\
\text { Access }>\text { no access to the } \\
\text { human tutor }\end{array}$} & \multicolumn{3}{|c|}{$\begin{array}{l}\text { Hypothesis 3: } \\
\text { Interaction effect }\end{array}$} \\
\hline & & & \multirow{2}{*}{$\frac{(\mathrm{HT})}{F \text { ratio }}$} & \multicolumn{4}{|l|}{$(\mathrm{CT})$} \\
\hline$F$ ratio & \multicolumn{2}{|c|}{$\begin{array}{l}\text { Levels of } \\
\text { significance }\end{array}$} & & $\begin{array}{l}\text { Levels of } \\
\text { significance }\end{array}$ & $F$ ratio & \multicolumn{2}{|c|}{$\begin{array}{l}\text { Levels of } \\
\text { significance }\end{array}$} \\
\hline 11.043 & VVS & 0.001 & 0.200 & 0.655 & 2.447 & NS & 0.118 \\
\hline
\end{tabular}

Explanations: the learner takes more notice of the promptings of the pro-active tutor to use the lexical help than to the items of lexical information received from the tutor

First, we may say that pro-active tutoring prompts the learner to use the lexical help equally with access to the HT tutor or with access to the CT tutor. Indeed, we observe that the difference between the number of promptings (see Table 8) when the pro-active mode of intervention is assured by the HT tutor (0.40) and when it is assured by the CT tutor (0.32) is not significant (NS at 0.53 on the $t$ test).

Secondly, there is a difference in terms of effect of the promptings given by the pro-active HT tutor when compared with those given by the pro-active CT tutor. Learners take notice of the pro-active promptings more systematically when HT tutors are accessible $(r=0.489 \mathrm{VVS}$ at 0.001$)$ than when they are not $(r=0.012 \mathrm{NS}$ at $0.860)$.

Lastly, if we consider the lexical information that, pro-active HT tutors provide, we observe that their promptings seem to have more influence than the information they may transmit. Indeed, if a systematic relation (VVS at 0.009 ) between the number of information items administered by the proactive HT tutor and the number of requests for lexical help is significant, the correlation coefficient is low $(r=0.164)$. The learner who receives lexical information thus has a tendency to use this help but it is the promptings of the tutor that seem to most stimulate the learner to use it. This is confirmed by the regression analysis (Table 10) where the weight associated with the number of promptings is greater $($ Beta $=0.413)$ than that associated with the number of items of information $($ Beta $=0.164)$ in order to explain the number of activations of the lexical tool.

It is important to make clear that the two variables integrated in the regression model (promptings and items of information) alone 
Table 10. Results of the regression analysis for pro-active tutoring by an HT tutor with respect to the lexical help

\begin{tabular}{llllllllll}
\hline \multicolumn{3}{l}{$\begin{array}{l}\text { Pro-active access to the HT } \\
\text { tutor }\end{array}$} & & & $\begin{array}{l}\text { Beta } \\
\text { value }\end{array}$ & & & $t$ sign. \\
\hline$R$ & 0.468 & $F$ & 29.011 & & Promptings & 0.413 & 6.630 & 0.000 & VVS \\
$R^{2}$ & 0.219 & $F$ sign. & 0.000 & VVS & $\begin{array}{l}\text { Items of } \\
\text { information }\end{array}$ & 0.164 & 2.627 & 0.009 & VVS \\
& & & & & & & \\
\hline
\end{tabular}

provide a degree of explanation for the use of the lexical help which attains $21 \%\left(R^{2}=0.219\right)$ and which may be considered high. The 'social presence' seems, in the case of the lexical help, to be less important than in the case of the metacognitive help, for which the degree of explanation provided by the variables (promptings and items of information) was much lower $(5 \%$, see Table 7$)$. This leads us to believe that the use of the metacognitive help could be explained by the social presence of the HT tutor, lacking other tangible elements.

\section{The conceptual help}

None of the variables under consideration has an effect on the use of the conceptual tool as confirmed by the analysis of variance (Table 12). In Table 11, we can observe that the average numbers of activations of the conceptual tool are very close whatever the mode of tutoring employed (between 0.50 and 0.56 ).

Concerning the promptings (Table 11), they are as frequent when the HT tutor is present $(0.32)$ as when the learner is faced with the

Table 11. Average number of items of conceptual help

\begin{tabular}{lllll}
\hline & $\begin{array}{l}\text { Reactive } \\
\text { access } \\
\text { to the } \\
\text { CT tutor }\end{array}$ & $\begin{array}{l}\text { Pro-active } \\
\text { access } \\
\text { to the } \\
\text { CT tutor }\end{array}$ & $\begin{array}{l}\text { Reactive } \\
\text { access } \\
\text { to the } \\
\text { HT tutor }\end{array}$ & $\begin{array}{l}\text { Pro-active } \\
\text { access } \\
\text { to the } \\
\text { HT tutor }\end{array}$ \\
\hline $\begin{array}{l}\text { Activation of the conceptual } \\
\text { help by learner }\end{array}$ & 0.56 & 0.50 & 0.51 & 0.55 \\
$\begin{array}{l}\text { Promptings by the tutor to use } \\
\text { the conceptual help }\end{array}$ & - & 0.32 & 0.07 & 0.29 \\
$\begin{array}{l}\text { Items of conceptual informa- } \\
\text { tion transmitted by the tutor }\end{array}$ & - & - & 0.20 & 1.28 \\
\hline
\end{tabular}


Table 12. Results of the analysis of variance relating to the activations by the learner of the navigational help

\begin{tabular}{|c|c|c|c|c|c|c|c|c|}
\hline \multicolumn{3}{|c|}{$\begin{array}{l}\text { Hypothesis } 1 \text { : } \\
\text { Pro-active }>\text { reactive }\end{array}$} & \multicolumn{3}{|c|}{$\begin{array}{l}\text { Hypothesis } 2 \text { : } \\
\text { Access }>\text { no access to the } \\
\text { human tutor }\end{array}$} & \multirow{2}{*}{\multicolumn{3}{|c|}{$\begin{array}{l}\text { Hypothesis } 3 \text { : } \\
\text { Interaction effect }\end{array}$}} \\
\hline & & & \multirow{2}{*}{$\begin{array}{l}\text { (HT) } \\
F \text { ratio }\end{array}$} & \multicolumn{2}{|c|}{$(\mathrm{CT})$} & & & \\
\hline$F$ ratio & \multicolumn{2}{|c|}{$\begin{array}{l}\text { Levels of } \\
\text { significance }\end{array}$} & & \multicolumn{2}{|c|}{$\begin{array}{l}\text { Levels of } \\
\text { significance }\end{array}$} & $F$ ratio & \multicolumn{2}{|c|}{$\begin{array}{l}\text { Levels of } \\
\text { significance }\end{array}$} \\
\hline 0.014 & NS & 0.905 & 0.000 & NS & 0.988 & 0.347 & NS & 0.556 \\
\hline
\end{tabular}

CT tutor (0.29). Here, it seems that pro-active tutoring stimulates the learner to use the conceptual help equally, whether the HT tutor is present or not.

If we look at the number of items of information provided when the HT tutor is pro-active, the application of the regression analysis (Table 13) shows that, of the two explanatory variables, promptings and received information, only the variable promptings is significant (VVS at 0.000) in the explanation of requests for conceptual help.

It seems then that the promptings to use the conceptual help are more systematically heeded when HT tutors are present than when they are absent, even though these promptings have little effect since the, use of the conceptual help does not vary considerably. The hypothesis of the 'social presence' does not hold here since pro-active HT tutoring does not favour a greater use of the conceptual help. Another explanation of the absence of effect of the conceptual help could be an inhibiting aspect of the conceptual help itself: because it is too complex, it becomes inaccessible to the learner. Indeed, its aim is to allow the learner to better understand the concepts contained in the software by giving access to, examples, detailed definitions,

Table 13. Results of the regression analysis for pro-active tutoring by an HT tutor, as regards the conceptual help

\begin{tabular}{|c|c|c|c|c|c|c|c|c|c|}
\hline & \multicolumn{5}{|c|}{$\begin{array}{l}\text { Pro-active access to the } \\
\text { HT tutor }\end{array}$} & \multirow{2}{*}{$\begin{array}{c}\begin{array}{l}\text { Beta } \\
\text { value }\end{array} \\
0.259\end{array}$} & \multirow{2}{*}{$\begin{array}{l}t \\
3.891\end{array}$} & \multicolumn{2}{|l|}{$t$ sign. } \\
\hline$R$ & 0.290 & $F$ & 9.469 & & Promptings & & & 0.000 & VVS \\
\hline$R^{2}$ & 0.084 & $F$ sign. & 0.000 & VVS & $\begin{array}{l}\text { Items of } \\
\text { information }\end{array}$ & 0.115 & 1.727 & 0.086 & NS \\
\hline
\end{tabular}


questions, etc. In order to use them optimally, it is essential that the learner realise the need for them, is motivated to use them and has the means to obtain the information. Concentrating on the main task, the problem which they are occupied at solving, the learners prefer to use the information they can obtain readily rather than 'wasting time' looking for the more complex items of information provided by the conceptual help. The cognitive overload that this investment would impose undoubtedly dissuades the learner. It may also be because items of information are easily available, their formulation succinct and immediately usable that the lexical and metacognitive forms of help are used more readily.

\section{The navigational help}

In Table 14, the average number of activations of the navigational help by the learner was greater when the CT tutor was available $(0.44$ and 0.49).

The analysis of variance (Table 15) confirms that the values are significantly lower where there is an HT tutor. This contradicts our original hypothesis. The other two hypotheses are invalidated. Therefore there is no effect due to pro-activity and no effect due to interaction.

Nevertheless some characteristics of pro-activity are similar to those of the other help tools considered earlier: pro-active tutoring stimulates the learner to use the navigational help equally (difference NS at 0.12 on the $t$ test between the averages) when the HT tutor is accessible (0.18) and when the HT tutor is not (0.35).

Table 14. Average number of occurrences of navigational help

\begin{tabular}{lllll}
\hline & $\begin{array}{l}\text { Reactive } \\
\text { access } \\
\text { to the } \\
\text { CT tutor }\end{array}$ & $\begin{array}{l}\text { Pro-active } \\
\text { access } \\
\text { to the } \\
\text { CT tutor }\end{array}$ & $\begin{array}{l}\text { Reactive } \\
\text { access } \\
\text { to the } \\
\text { HT tutor }\end{array}$ & $\begin{array}{l}\text { Pro-active } \\
\text { access } \\
\text { to the } \\
\text { HT tutor }\end{array}$ \\
\hline $\begin{array}{l}\text { Activation of the navigational } \\
\text { help by the learner }\end{array}$ & 0.44 & 0.49 & 0.35 & 0.21 \\
$\begin{array}{l}\text { Promptings by the tutor to use } \\
\text { the conceptual help }\end{array}$ & - & 0.35 & 0.13 & 0.18 \\
$\begin{array}{l}\text { Items of navigational informa- } \\
\text { tion transmitted by the tutor }\end{array}$ & - & 1.37 & 0.48 & 1.48 \\
\hline
\end{tabular}


Table 15. Results of the analysis of variance relating to the activations by the learner of the navigational help

\begin{tabular}{|c|c|c|c|c|c|}
\hline \multirow{2}{*}{\multicolumn{2}{|c|}{$\begin{array}{l}\text { Hypothesis } 1 \text { : } \\
\text { Pro-active }>\text { reactive }\end{array}$}} & \multicolumn{2}{|c|}{$\begin{array}{l}\text { Hypothesis 2: Access }> \\
\text { no access to the human } \\
\text { tutor }\end{array}$} & \multirow{2}{*}{\multicolumn{2}{|c|}{$\begin{array}{l}\text { Hypothesis 3: Interaction } \\
\text { effect }\end{array}$}} \\
\hline & & $(\mathrm{HT})$ & $(\mathrm{CT})$ & & \\
\hline$F$ ratio & $\begin{array}{l}\text { Levels of } \\
\text { significance }\end{array}$ & $F$ ratio & $\begin{array}{l}\text { Levels of } \\
\text { significance }\end{array}$ & $F$ ratio & $\begin{array}{l}\text { Levels of } \\
\text { significance }\end{array}$ \\
\hline 0.517 & 0.472 & 6.490 & 0.011 & 1.719 & 0.190 \\
\hline
\end{tabular}

Moreover, the pro-active tutor, HT or CT, provides the learners with about the same number of information items (1.48 and 1.37, Table 14). However the respective effects of the items of information administered are different. Indeed, the analyses of regression (Tables 16 and 17) clearly show that the variable 'Promptings' is never significant (NS at 0.556 and NS at 0.055 ) whereas the number of items of information intervenes in explaining the number of activations of the navigational help (Beta $=0.396 \mathrm{VVS}$ at 0.000 ). The number of item of information given by the pro-active CT tutor does not figure in the explanation of the number of activations of the navigational help $($ Beta $=0.034 \mathrm{NS}$ at 0.883$)$. The amount of information transmitted by the tutor has an influence on the number of uses of the navigational help only when the pro-active $H T$ tutor is accessible. In this case, the more items of navigational information the tutor gives, the more the learner calls on the navigational help.

It would seem that, when compared with dialogue with an HT tutor, the navigational help is perhaps not the most appropriate channel of information for informing the learner about how to move around in the system. Indeed, the number of uses of the navigational help was the lowest of all the help tools (0.21, see Table 14). Our

Table 16. Results of the regression analysis concerning navigational help for the proactive tutoring mode assured by a CT tutor

\begin{tabular}{llllllllll}
\hline \multicolumn{3}{c}{$\begin{array}{l}\text { Pro-active access } \\
\text { tutor }\end{array}$} & & & $\begin{array}{l}\text { Beta } \\
\text { value }\end{array}$ & $t$ & & $t$ sign. & \\
\hline$R$ & 0.167 & $F$ & 2.976 & & Promptings & 0.135 & 0.590 & 0.556 & NS \\
$R^{2}$ & 0.028 & $F$ sign. & 0.053 & NS & $\begin{array}{l}\text { Items of } \\
\text { information }\end{array}$ & 0.034 & 0.147 & 0.883 & NS \\
\hline
\end{tabular}


Table 17. Results of the regression analysis concerning navigational help for the proactive tutoring mode assured by an HT tutor

\begin{tabular}{llllllllll}
\hline \multicolumn{4}{l}{$\begin{array}{l}\text { Pro-active access to the HT } \\
\text { tutor }\end{array}$} & & & $\begin{array}{c}\text { Beta } \\
\text { value }\end{array}$ & & & \multirow{2}{*}{$t$ sign. } \\
\hline$R$ & 0.476 & $F$ & 30.290 & & Promptings & 0.134 & 1.926 & 0.555 & NS \\
$R^{2}$ & 0.226 & $F$ sign. & 0.000 & VVS & $\begin{array}{l}\text { Items of } \\
\text { information }\end{array}$ & 0.396 & 5.679 & 0.000 & VVS \\
& & & & & & & \\
\hline
\end{tabular}

explanatory hypothesis is that the items of information transmitted by the proactive HT tutor, if they stimulate the learner to use the navigational help more often, sometimes carry items of information so appropriate that the learner no longer sees the necessity of calling on the navigational help.

In the case of the navigational help, when the learners are encouraged to use it more intensively, many do not. Taking this fact into consideration, the tutors progressively give the learners the items of information they clearly need. The tutors may not confine themselves to the role of being counsellor at a specific time; they must also give clear information, If we try to explain the reasons why the HT tutor was called upon in preference to a computerised help tool for all navigational matters, we may think that if learners have problems in manipulating the system, they are not going to use the system's resources and therefore are not going to use the navigational help. Instead the learner seeks a more familiar channel, such as calling upon an HT tutor. This is the founding principle of helpdesks. This explanation, if it proves to be appropriate, raises questions as to the necessity and value of installing navigational help tools.

\section{Which modes of tutoring encourage learners to use computerised help?}

\section{Encouraging the learner to use a help tool increases its use}

It is essential to distinguish between the different types of help according to their role. Indeed, our results are not consistent for the different help tools. Help should therefore not be considered as a single concept having a single effect, but rather as a set of distinct functions.

The first, and the most natural, hypothesis is that a learner will use a tool more if they receive prompting from the tutor to do so. Our analysis shows a pro-active effect, which consequently gives rise to an 
increase in the overall use that the learner makes of the help tools. This hypothesis is statistically verified for the metacognitive help and the lexical help, but not for either the conceptual help or the navigational help. According to the mode employed, the intervention of the tutors either stimulates or does not stimulate the learners to make greater use of the help tools placed at their disposal. This seems to us to be in agreement with the observations of Mason (1992) who concludes that the way in which tutors intervene has more impact than the number of times they intervene.

Pro-activity has an intensifying effect on the intrinsic qualifies of a help tool

One of the effects of pro-activity is to stimulate the learners to use the help tools: but are learners always compliant? From a general point of view, our reply is that they are not. Indeed, while they followed the tutor's promptings for the lexical help and to a lesser degree for the metacognitive help, they adopted the opposite behaviour for the navigational help. The learners apparently adopted a spontaneous use of the help tools which went beyond the promptings of the tutor. This seems to be linked to two characteristics of the tool: the contextualisation of help and its ease of use.

Contextualisation of the information provided is related to its relevance to the problem the learner is trying to solve. For example, when learners activated the metacognitive help, the help delivered an item of information updated in relation to the evolution of the learners in their learning process by showing them the answers they had given since the beginning of their session. Metacognitive help was much more contextualised than the other help tools. For the latter, learners had to select the relevant information from an index (for the glossary) or headings (for the conceptual help and the navigational help). They had to identify them on their own initiative without automatically obtaining the help that was going to be the most appropriate to their difficulty. The criterion of contextualisation was thus satisfied for the metacognitive help but not for the others. Knowing that not all learners have the same capacity to identify gaps in their knowledge or difficulties in terms of their level of cognitive (Person et al., 1994) and metacognitive abilities, it is not surprising that these help tools were scarcely used without promptings to do so.

If the glossary was nevertheless used more than the conceptual and navigational help, it is because it was easier to find information therein. 
Ease of access depends on the means of reaching the information and on the form in which the information is presented. Access that requires a series of manipulations or a long search for information does not encourage the use of this help, whereas a presentation of key words giving immediate access to a relevant item of information does encourage its use.

We argue that learners chose the type of help according to the quality of the information and the rapidity with which it is provided.

If the cognitive and manipulatory accessibility of the glossary compensated for its lack of contextualisation, this was not the case for the navigational help and the conceptual help, which were not used often. Conclusions relating to the navigational help proposed in this text may be even better understood when the dialogues between the tutor and the learner are analysed (Delrane, in preparation). Indeed, dialogues are often used to help the learner navigate.

The elements we have just put forward lead us to make the observation that pro-activity has the effect of enhancing the intrinsic qualities of the help tool. It is important to benefit from help that is appropriate, accessible and contextualised. When these qualities are combined, pro-activity leads to a greater use of the help tool. On the other hand, if some of these qualities are lacking, pro-activity loses much of its efficacy. Even when these qualities exist, they are not always sufficient to persuade learners to use the help tools. One explanation of the minimal use that is made of them is very often linked to the fact that their content is not well known to the learners (Posner et al., 1992; Deschryver et al., 1994; Dijkstra et al., 1999). Pro-active behaviour by the tutor may stimulate the learners to discover the content of these help tools in their context as well as how to access the information they convey.

\section{Does the presence of an HT tutor influence the use of help tools?}

The hypothesis that the learners use help more if they have been prompted by an HT tutor is not supported for any of the four help tools under consideration. The only observed effect of the HT tutor is an inhibiting effect on the use of the navigational help. However, comparison of the averages of each group masks differences between individuals: some students use some types of help more than others. And, when the HT tutor prompts the learner, the correlation coefficients (Table 18) between the number of promptings and the number of activations are significant, whereas they are not when the learner 
Table 18. Bravais Pearson, correlation coefficients between the number of promptings and activations of help

\begin{tabular}{llllllll}
\hline & \multicolumn{3}{l}{ Pro-active access to the CT tutor } & \multicolumn{2}{l}{$\begin{array}{l}\text { Pro-active } \\
\text { access to the } \\
\text { HT tutor }\end{array}$} \\
\hline Metacognitive help & $r=0.131$ & 0.058 & NS & $r=0.187$ & 0.007 & VVS \\
Lexical help & $r=0.012$ & 0.860 & NS & $r=0.489$ & 0.001 & VVS \\
Conceptual help & $r=0.125$ & 0.070 & NS & $r=0.266$ & 0.00 & VVS \\
Navigational help & $r=0.127$ & 0.015 & NS & $r=0.315$ & 0.000 & VVS \\
\hline
\end{tabular}

receives promptings from a $\mathrm{CT}$ tutor. This observation is verified for the metacognitive, lexical and conceptual helps.

The learners would seem to be more sensitive to the injunctions of an HT tutor than to those coming from a CT tutor. We must employ the conditional here since, on the one hand, the correlation coefficients are low and, on the other hand, comparison between the correlation coefficients cannot be substituted for the absence of effect observed in the analysis of variance concerning the effect of the accessibility/non-accessibility of the human tutor variable.

Interpretation of these results remains complex, however, because another process interferes with the one which has just been described: not only may the tutors encourage the learner to ask for a specific type of help, but they may also supply information of the same type as that given by a specific form of help. Is this information going to inhibit use of the help tools? (One does not need to seek the items of information which one has just been given.) Or, on the contrary, is it going to stimulate their use? (One perceives the usefulness of the information which one is able to find in a particular help tool.) The second explanation seems more appropriate for the metacognitive, lexical and navigational help: the more items of information the students receive, the more they seek.

Let us note that, for the navigational help, the correlations are higher than for the other help tools. This observation, coupled with the inhibiting effect observed in the analysis of variance, seems to us to confirm that navigational help may not be transmitted easily in a learning set-up by a tool which itself calls on the navigational abilities required by the set-up. This observation also seems to us to confirm that it is necessary, consequently, to use a more natural information channel, such as discussion with an HT tutor available at a distance. 


\section{Conclusions}

About pro-activity, our conclusion is that the best way to bring learners to use a tool is not only to tell them to do so but also to provide them with information that invites them to activate the tool. Tutoring is a subtle process. The second conclusion is that this study did not reveal an effect of HT tutoring that would be significant enough to justify its cost.

The picture that comes out of the study is that the tutor and the help tools form a complex and dynamic system. It is complex because the relationship between the help provided by the tutor and the help provided by the tools varies from one tool type to another (lexical, navigational, conceptual, metacognitive). It is dynamic because this relationship evolves with time, the original configuration of tools may be rapidly modified through interactions. Moreover, it is personal.

One of the implications of this research relates to the way in which the needs of learners are taken into account. Like Karabenick \& Knapp (1991), we think that it is necessary to inform learners of the conditions in which the use of help tools is appropriate to helping them succeed. In order to do this, we join Deschênes \& Lebel (1994) in proposing that the tutor should decide on the mode of intervention to be used for a given learner. This choice of the type of intervention must be taken together with the learner (Bernatchez, 1998; Gagné et al., 2001) in order for it to be as appropriate as possible. Putting in place the conditions for a better adaptation of the tools to the needs of learners means offering a space in which the tutor and the learner may converse openly and sincerely. We shall be considering the complementarity between dialogue tools and computerised help tools in the near future.

\section{References}

Annoot, E. (2001). Le tutorat ou «le temps suspendu». Revue des sciences de l'éducation 27(2): 383-402.

Bajtelsmit, J.W. (1988). Predicting distance learning dropouts: Testing a conceptual model of attrition in distance education. Report to the ICDE Research Committee.

Belawati, T. (1998). Increasing student persistence in Indonesian post-secondary distance education. Distance Education 19(1): 81-109.

Bernard, R. \& Naidu, S. (1990). Enhancing interpersonal communication in distance education: can «Voice-mail» help?. Educational and Training Technology International 27(3): 293-300.

Bernatchez, P.-A. (1998). L'encadrement des apprenants par la télématique. Distances 2(2): 65-79. 
Bertrand, L., Demers, L. \& Dion, J.-M. (1994). Contrer l'abandon en formation à distance: expérimentation d'un programme d'accueil aux nouveaux étudiants à la Télé-université. Journal of Distance Education/Revue de l'enseignement à distance 9(2): $1-10$.

Blay, T. (1994). How to reactivate drop-outs. Epistolodidaktika 1: 40-48.

Bourdages, L. \& Delmotte, C. (2001). La persistance aux études universitaires à distance. Journal of Distance Education/Revue de l'enseignement à distance 16(2): $1-1$.

Burge, E. (1994). Learning in computer-conferencing contexts: the learner's perspective. Journal of Distance Education/Revue de l'enseignement à distance 9(1): 19-43.

Burge, E., Howard, J.L. \& Ironside, D.J. (1991). Mediation in distance learning: An investigation of the role of tutoring. Ontario: Ontario Institute for Studies in Education(ERIC Document Reproduction Service No ED 339 349).

Carrier, G. \& Schofield, M. (1991). Student support and computer mediated communication in distance education. Canadian Journal of Educational Communication 20(1): 45-54.

Choi, J.-I. \& Hannafin, M. (1995). Situated cognition and learning environments: roles, structures and implications for design. Educational Technology Research \& Development 43(2): 53-69.

Collins, A. (1996). Design issues for learning environments. In S. Vosniadou, E.D. Corte, R. Glaser and H. Mandl, (eds), International perspectives on the design of technology-supported learning environments, pp. 347-362. Erlbaum: Mahwah, NJ.

Collis, B. \& Pals, N. (1998). A model for predicting an individual's use of a telematics application for a learning-related purpose. International Journal of Educational Telecommunications 6(1): 63-103.

Crook, C.K. (1994). Computers and the collaborative experience of learning. London: Routledge.

Denis, B. (2003). Quels rôles et quelle formation pour les tuteurs intervenant dans des dispositifs de formation à distance?. Distances et savoirs 1(1): 19-46.

Depover, C., De Lièvre, B. \& Pingaut, A. (1998). Analyse de quelques facteurs susceptibles d'agir sur la fidélisation dans un cours d'enseignement à distance. Scientia Paedagogica Experimentalis 15: 315-336.

Deschênes, A.-J. \& Lebel, C. (1994). La conception du supportà l'apprentissage dans les activités de formation à distance. In A.-J. Deschênes, (eds), La formation à distance maintenant. Manuel d'apprentissage. Thème II. Le support à l'apprentissage et formation à distance, Téléuniversité: Sainte-Foy.

Deschryver, N., Depover, C. \& Liè4vre, B. De (1994). Analyse comparative des démarches d'apprenants novices et experts dans une situation de résolution de problèmes assistée par ordinateur. Université de Mons-Hainaut: Publication interne. Mons.

Desmarais, L. (2000). La persévérance dans l'enseignement à distance. In T. Chanier and M. Pothier, (eds), Systèms d'information et de communication dans des situations diversifiées d'apprentissage des langues 3(1): 49-59.

Dijkstra, S., Collis, B. \& Eseryel, D. (1999). Instructional Design for Tele-learning. Journal of Computing in Higher Education 10(2): 3-18.

Gagné, P., Bégin, J., Laferrière, L., Léveillé, P. \& Provencher, L. (2001). L’encadrement des études à distance par des personnes tutrices: qu'en pensent les étudiants?. Distances 5(1): 59-83.

Glikman, V. (1999). Formations à distance: au nom de l'usager. Distances 3(2): 101-117. 
Goodyear, P. (2002). Teaching online. In N. Hativa and P. Goodyear, (eds), Teacher thinking, beliefs and knowledge in higher education, pp. 79-101. Kluwer Academic Publishers: Dordrecht.

Goodyear, P., Salmon, G., Spector, M., Steeples, C. \& Tickner, S. (2001). Competences for online teaching. Educational Technology Research \& Development 49(1): $65-72$.

Gregor, S. \& Cuskelly, E. (1994). Computer mediated communication in distance education. Journal of Computer Assisted Learning 10: 168-181.

Hardy, V. (1992). Introducing computer mediated communication into participative management education: the impact on the tutor's role. Education and Training Technology International 29: 325-331.

Henri, F. \& Kaye, A. (1985). Le savoir à domicile. Sainte-Foy: Presses de l'Université du Québec et Télé-université.

Karabenick, S. \& Knapp, J. (1991). Relationship of academic help seeking to the use of learning strategies and other instrumental achievement behavior in college students. Journal of Educational Psychology 83: 221-230.

Kelly, B. (1993). Increasing student retention rates. Distance Education Association of New Zealand Bulletin 16: 21-28.

Laurent, J., Gagné-Iattioni, L. \& Lessard, M. (1992). Le tutorat: un office de médiation controversé: Recherche sur la relation tuteur-étudiant à la Télé-université. Québec: Télé-université, Bureau de planification et de recherche institutionnelle.

Lebel, C. (1995). Le tuteur et l'autonomie de l'étudiant à distance. Journal of Distance Education/Revue de l'enseignement à distance 10(1): 5-24.

Lebel, C. \& Michaud, B. (1989). Le tuteur et le support à l'étudiant en enseignement à distance. In R. Sweet, (ed.), Post-secondary Distance Education in Canada. Policies, Practices and Priorities. ED 336648.

Legendre, R. (1993). Dictionnaire actuel de l'éducation. Montréal: Guérin-Eska.

Mason, R. (1990). Computer conferencing: An example of good practice. CITE report no. 129, Institute of Educational Technology, The Open University.

Mason, R. (1992). Application of electronic communication, for distance education in the third world. Bangkok Project. Bangkok: Thailand.

Mason, R. \& Weller, M. (2000). Factor affecting student's satisfaction on a web course. Australian Journal of Educational Technology 16(2): 173-200.

Paquette, D. (2001). Le rôle des tuteurs et des tutrices: une diversité à appréhender. Distances 5(1): 7-35.

Person, N., Graesser, A., Magliano, J. \& Kreuz, R. (1994). Inferring what the student knows in one-to-one tutoring: the role of student questions and answers. Learning and Individual Differences 6: 205-229.

Pettigrew, F. (2001). L'encadrement des cours à distance: profils étudiants. Distances 5(1): 99-112.

Portway, P. \& Lane, C. (1997). Guide to teleconferencing and distance learning. Cleveland, OH: Advanstar Communications.

Posner, B., Danielson, R. \& Schmidt-Posner, J. (1992). Factors in the adoption and use of an electronic communication system for MBA students. Journal of Educational Technology Systems 21: 1-14.

Power, M., Dallaire, S., Dionne, M. \& Théberge, C. (1994). L' encadrement des étudiantes et des étudiants en situation d'apprentissage à distance à l'Université $d u$ Québec à Rimouski (Monographie no 42). Rimouski: Université du Québec à Rimouski. 
Salmon, G. (2000). E-moderating: The Key to Teaching and Learning Online. London: Kogan Page.

Salomon, G., Globerson, T. \& Guterman, E. (1989). The computer as a zone of proximal development: Internalizing reading-related metacognitions from a reading partner. Journal of Education Psychology 89: 620-627.

Schweizer, K., Paechter, M. \& Weidenmann, B. (2001). A field study on distance education and communication: experiences of a virtual tutor. Journal of Computermediated Communication 6: 2-12.

Sherry, L. (2000). The nature and purpose of online conversations: a brief synthesis of current research. International Journal of Educational Telecommunications 6(1): 1952.

Stevenson, K., Sander, P. \& Naylor, P. (1996). Student perceptions of the tutor's role in distance learning. Open learning 11(1): 22-30.

Taplin, M., Yum, J., Jegede, O., Fan, R. \& Chan, M. (2001). Help-seeking strategies used by high-achieving and low-achieving distance education students. Journal of Distance Education/Revue de l'enseignement à distance 16(1): 56-69.

Tinto, V. (1987). Leaving college: Rethinking the causes and curses of student attrition. Chicago: University of Chicago.

Towles, D. (1993) Student persistence in a distance education program: The effect of faculty initiated contact. AIR Annual forum paper. Virginia, USA. (ERIC Document Reproduction Service No. ED 360 931).

Vygotsky, L. (1981). Mind in society. Cambridge, MA: Harvard University Press.

Weedon, E. (1997). A new framework for conceptualizing distance learning. Open Learning 12(1): 40-44.

Wood, D., Bruner, J. \& Ross, G. (1976). The role of tutoring in problem solving. Journal of Child Psychology and Psychiatry 17: 89-100.

Wozniak, H. \& Silviera, S. (2004). Online discussions: Promoting effective student to student interaction. In R. Atkinson, C. McBeath, D. Jonas-Dwyer and R. Phillips, (eds), Beyond the comfort zone: Proceedings of the 21st ASCILITE Conference (pp. 956-960).

Young, M. (1993). Instructional design for situated learning. Educational Technology Research \& Development 41(1): 43-58. 